\title{
Use of deproteinizer to eliminate interference of high bilirubin on measurement of serum creatinine by the kinetic jaffe reaction
}

\author{
Vijaysinh Parmar $^{1}$, Hiren Sanghani ${ }^{2, *}$, Asha Khubchandani ${ }^{3}$ \\ ${ }^{1,2}$ Assistnat Professor, ${ }^{3}$ Professor \& HOD, Dept. of Biochemistry, ${ }^{1}$ Smt. NHL Municipal Medical College, Ahmedabad, Gujarat, \\ ${ }^{2}$ GMERS Medical College, Gandhinagar, Gujarat, ${ }^{3} \mathrm{~B}$. J. Medical College, Ahmedabad, Gujarat, India
}

Received: $14^{\text {th }}$ November, 2017

\author{
*Corresponding Author: \\ E-mail: hirensanghani@gmail.com
}

\begin{abstract}
Introduction: Serum creatinine is a useful diagnostic parameter of kidney function. Its concentration reflects glomerular filtration rate. Because of negative interference of bilirubin over creatinine level, may mislead the clinician. The most common and serious problems in the determination of serum creatinine concentration by the kinetic Jaffe method is the negative interference by bilirubin.

Materials and Methods: This cross sectional study was done on 160 patients which have high bilirubin level, taken from B. J. Medical College, Civil hospital, Ahmedabad from August 2013 to December 2013. These samples were studied for interference of total bilirubin on measurement of Serum creatinine level before and after treating with deproteinizer (trichloroacetic acid 0.55 $\mathrm{mmol} / \mathrm{ltr}$ ). Serum bilirubin and serum creatinine level were measured by modified Jendrassik \& Groff's method and kinetic Jaffe's reaction respectively by using Erba XL-640 fully auto analyzer.

Results: In this study significant difference was found in Serum Creatinine level with the samples of high bilirubin content before and after treating with deproteinizer (trichloroacetic acid) $(\mathrm{p}<0.01)$. This result shows negative interference of Serum Bilirubin on serum creatinine estimation. Preprecipitation of albumin along with bilirubin by trichloroacetic acid beforehand is suggested as an approach to correct the bilirubin interference.

Conclusion: From this study it is concluded that bilirubin have negative interference on serum creatinine level. And this is corrected by using deproteinizer trichloroacetic acid.
\end{abstract}

Keywords: Serum Creatinine, Serum bilirubin, Negative intereference.

\section{Introduction}

Serum creatinine is a useful index of kidney function. Its concentration reflects glomerular filtration rate. ${ }^{1}$ At present, most discrete chemical analyzers use direct kinetic jaffe reaction to assay creatinine in patient serum because there is no need to remove protein from sample before the reaction. ${ }^{2}$ The kinetic method can correct interference from slow reacting non-creatinine chromogens such as glucose, acetone, ascorbic acid. ${ }^{2,3}$ However, fast reacting substance such as alpha keto compounds and cephalosporin antibiotics give positive interference. ${ }^{4}$ While serum bilirubin gives negative interference on creatinine results. ${ }^{1,4}$

Bilirubin interference with serum creatinine measurements is a still a serious concern for clinical labs. The interference can have clinical significance as we use the creatinine level to monitor the effect of nephrotoxic drugs and adjust the dose of drug that excrete through the kidney such as aminoglycosides. Because of negative interference of bilirubin over creatinine level, may mislead the clinician in prescribing the same dose of the drugs. The overdose of aminoglycosides may cause permanent deafness in the patients. The Jaffe reaction for estimating serum creatinine is widely used in many laboratories despite certain disadvantages, particularly regarding analytical specificity and assay interference from several compounds present in serum. For example, many oxidoreductive compounds react with the alkaline sodium picrate to either increase or decrease the apparent creatinine concentration..$^{5,6}$ One of the most common and serious problems in the determination of serum creatinine concentration by the Jaffe kinetic method is the negative interference by bilirubin. ${ }^{6-9}$

The interference of bilirubin with the Jaffe alkaline picrate method for estimating serum creatinine is particularly disturbing in assays performed by automated analyzers requiring small serum volumes without deproteinization. ${ }^{5,6,9}$ To overcome these problems, we propose an approach that prevents the interference by oxidizing bilirubin with tri chloroacetic acid(TCA). This approach is based on earlier observations that oxidation of bilirubin abolishes its interfering effect in the picric acid creatinine assay and that the enzymatic oxidation of bilirubin is faster and more efficient with the free (unbound) than with the protein-bound bilirubin. ${ }^{5}$ This new approach resolves the problem of bilirubin interference with the Jaffe reaction by introducing a preceding reaction in which bilirubin is displaced from albumin. ${ }^{10-12}$

Removing bilirubin along with albumin by trichloroacetic acid beforehand was suggested as an approach to correct the bilirubin interference. ${ }^{13}$ The separation of bilirubin along with albumin-either through the membrane layer before the enzymatic 
reaction or by manual acid deproteinization -before the kinetic reaction seems to be the best approach to correct bilirubin interference on serum creatinine. ${ }^{13,14}$

The introduction of some new enzymatic methods for the determination of creatinine, as well as an interesting proposed modification of the two-point, fixed-time kinetic procedure in which a pre-incubation step is used to eliminate bilirubin interference, has prompted us to compare these new techniques with regard to the interference of pseudocreatinines in serum. $^{15}$

\section{Materials and Methods}

This cross sectional observational study was done on 160 patients which have altered bilirubin level and altered urea level, taken from B. J. Medical College, Civil hospital, Ahmedabad from August 2013 to December 2013. All subjects were in age group of 20 to 60 years. We have included in Study Group A having Serum Total Bilirubin level $<1 \mathrm{mg} / \mathrm{dl}$ and serum urea level > $40 \mathrm{mg} / \mathrm{dl}$. Study group B having Serum Total Bilirubin level between 1 to $25 \mathrm{mg} / \mathrm{dl}$ and serum urea level $>40 \mathrm{mg} / \mathrm{dl}$. We have included in Control Group I having Serum Total Bilirubin level $<1 \mathrm{mg} / \mathrm{dl}$ and serum urea level $\leq 40 \mathrm{mg} / \mathrm{dl}$. Control group II having Serum Total Bilirubin level between 1 to $25 \mathrm{mg} / \mathrm{dl}$ and serum urea level $\leq 40 \mathrm{mg} / \mathrm{dl}$. We excluded sample of age $<20$ or $>60$, patients taking cephalosporin, aminoglycoside antibiotics, diabetic patients. These samples were studied for interference of total bilirubin on measurement of Serum creatinine level. So we have done serum creatiine level before and after treating with deproteinizer (trichloroacetic acid $0.55 \mathrm{mmol} / \mathrm{ltr}$ ). We also measure serum Urea level to compare with serum Creatinine level. Serum bilirubin and serum creatinine level were measured by modified Jendrassik \& Groff's method and kinetic Jaffe's reaction respectively by using Erba XL-640 fully auto analyzer. ${ }^{16-18}$ And serum urea level by Urease- GLDH, Enzymatic U.V. Kinetic method by using Erba XL-640 fully auto analyzer. ${ }^{19,20}$

We have done serum Bilirubin, serum Creatinine and serum urea in each sample. Than we add TCA (trichloroacetic acid $0.55 \mathrm{mmol} / \mathrm{ltr}$ ) in $2: 1$ ration (serum:TCA), put it for 20-30 minute than centrifuge again and collect supernatant fluid and perform serum Creatinine estimation again. We precipitated protein in each serum by adding trichloro acetic acid. We have done all test in a fully automated Erba XL-640 in a HiTech Laboratory, civil hospital, Ahmedabad.

\section{Statistical analysis}

Statistical analysis done by Graph Pad in stat software to support my study. Results obtained were summarized as (mean \pm standard deviation). Differences between the groups were compared using Student t-test, and the level of significance was set at $\mathrm{p}<0.05$.

\section{Result}

A total of one hundred and sixty (160) subjects were recruited for the study. All subjects divided in to four groups (Study group A \& B and Control group I \& II) as described in material and method.

Table 1 shows Comparision of S. Creatinine level before and after deproteinization in Study Group A \& Group B. There was no significant ( $p>0.05)$ difference in serum creatinine level in group A before and after deprotenization. But there was significant $(p<0.01)$ difference in serum creatinine level in group B before and after deprotenization. Fig. 1 shows Comparision of S. Creatinine before and after deprotenization in Group A and Fig. 2 shows Comparision of S. Creatinine before and after deprotenization in Group B.

Table 1: Comparision of S. Creatinine level before and after deproteinization in Study Group A \& Group B

\begin{tabular}{|l|c|c|c|}
\hline & $\begin{array}{c}\text { S. Urea Level } \\
(>\mathbf{4 0 ~ m g / d l})\end{array}$ & \multicolumn{2}{|c|}{ S. Creatinine Level } \\
\hline & & $\begin{array}{c}\text { Before } \\
\text { deproteinization }\end{array}$ & $\begin{array}{c}\text { After } \\
\text { deproteinization }\end{array}$ \\
\hline $\begin{array}{l}\text { Group A }(\mathrm{n}=40) \\
\text { (Bilirubin }<1 \mathrm{mg} / \mathrm{dl})\end{array}$ & $119 \pm 6.4$ & $1.8 \pm 0.22$ & $1.82 \pm 0.34$ \\
\hline $\begin{array}{l}\text { Group B }(\mathrm{n}=40) \\
\text { (Bilirubin } 1-25 \mathrm{mg} / \mathrm{dl})\end{array}$ & $127 \pm 5.6$ & $0.9 \pm 0.54$ & $2.33 \pm 0.49$ \\
\hline
\end{tabular}

Table 2 shows Comparision of S. Creatinine level before and after deproteinization in Control Group I \& Group II. There was no significant ( $p>0.05$ ) difference in serum creatinine level in Control Group I \& Control Group II before and after deprotenization in control group I and II. 
Table 2: Comparision of S. Creatinine level before and after deproteinization in Control Group I \& Group II

\begin{tabular}{|l|c|c|c|}
\hline & $\begin{array}{c}\text { S. Urea Level } \\
(\leq \mathbf{4 0 ~ m g / d l})\end{array}$ & \multicolumn{2}{|c|}{ S. Creatinine Level } \\
\hline & & $\begin{array}{c}\text { Before } \\
\text { deproteinization }\end{array}$ & $\begin{array}{c}\text { After } \\
\text { deproteinization }\end{array}$ \\
\hline $\begin{array}{l}\text { Group I }(\mathrm{n}=40) \\
(\text { Bilirubin }<1 \mathrm{mg} / \mathrm{dl})\end{array}$ & $28.40 \pm 3.06$ & $0.42 \pm 0.21$ & $0.43 \pm 0.16$ \\
\hline $\begin{array}{l}\text { Group II }(\mathrm{n}=40) \\
\text { (Bilirubin } 1-25 \mathrm{mg} / \mathrm{dl})\end{array}$ & $30.32 \pm 2.6$ & $0.56 \pm 0.22$ & $0.57 \pm 0.21$ \\
\hline
\end{tabular}

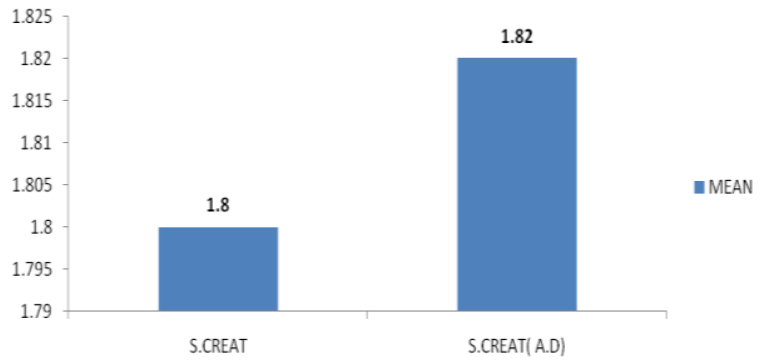

Fig. 1: Comparision of S. Creatinine before and after deprotenizer in Group A (p.0.05)

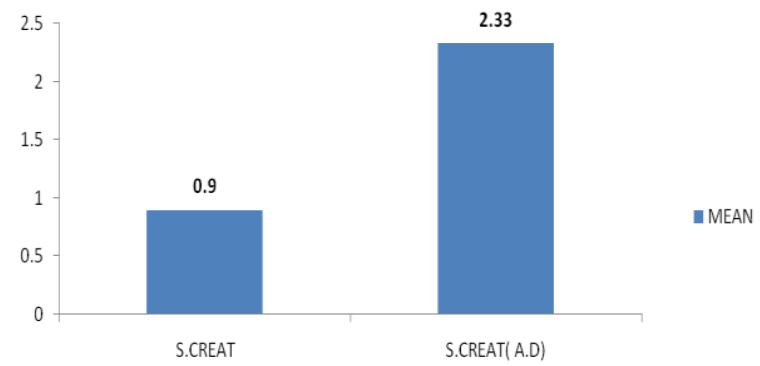

Fig. 2: Comparision of $S$. Creatinine before and after deprotenizer in Group $B(\mathbf{p}<0.01)$

\section{Discussion}

Serum Creatinine is a very useful parameter for renal function. It is most common and important parameter used to detect proper functioning of kidney. ${ }^{1}$ High performance liquid chromatography, gaschromatography with mass spectrometry methods have been developed as reference methods for creatinine estimation but the special instrumentation required for these methods is still an economic constraint in most of the laboratories in developing countries. The kinetic alkaline picrate (Jaffe's) method is used with various clinical laboratory instruments to determine serum creatinine. ${ }^{21,22}$

Oxidation of both conjugated and unconjugated bilirubin to biliverdin by either bilirubin oxidase or horse-radish peroxidase and hydrogen peroxide and the subsequent oxidation of biliverdin to a pale Diazonegative polar pigment cause characteristic absorption peaks of bilirubin to disappear. ${ }^{23-25}$ Broderson and Bartels noted that albumin inhibits the oxidation, suggesting that dissociation of bilirubin from albumin or other carrier proteins could facilitate its oxidation. ${ }^{23}$ Low $\mathrm{pH}$ as well as several compounds that binds to proteins promotes the displacement of bilirubin from albumin. ${ }^{11,26}$ The oxidation of bilirubin abolished its ability to interfere with the jaffe's Creatinine assay. ${ }^{27}$ The ability to displace bilirubin and to subsequently efficiently oxidize free bilirubin as successfully used to strongly reduce negative interference of bilirubin in to kinetic jaffe's reaction for determination of Creatinine..$^{28}$ Removing bilirubin along with albumin by trichloroacetic acid beforehand was suggested as an approach to correct the bilirubin interference. ${ }^{13}$

In present study we use TCA (trichloroacetic acid $0.55 \mathrm{mmol} / \mathrm{ltr}$ ) for precipitation of protein. In this study we have compare serum creatinine estimation before and after deproteinization and we found significant different $(p<0.01)$ in study Group B. Though the influence of the interfering substances has been found to be less frequent with enzymatic procedure than with Jaffe's kinetic method yet the Jaffe's method has the benefit of cost effectiveness. ${ }^{29}$ Moreover, the enzymatic methods do not show complete specificity to Creatinine. ${ }^{30}$ Therefore, the Jaffe's kinetic method is still a method of choice as the bilirubin interference can be reduced by using TCA precipitation approaches. ${ }^{14}$ Our findings of study is well correlate with other studies like Lolekha PH et al, ${ }^{31}$ Prabhat Kumar Nigam ${ }^{16}$ etc.

From this study it is found that bilirubin have negative interference on serum creatinine level. So, we have concluded that deproteinized serum before the reaction is the best approach to eliminate all forms of bilirubin interference on serum creatinine determined by the kinetic Jaffe reaction.

\section{References}

1. Spencer K. Analytical reviews in clinical biochemistry:the estimation of cretinine. Ann clin Biochem 1986;23:1-25.

2. 2.Fabiny DL,Ertingshausen GE. Automated reaction-rate method for determation of serumcreatinine with centrifichem. Clin chem. 1971;18:696-7010.

3. 3.Cook JGH.Creatinine assay in the precence of protein. Clin chem. Acta 1971;32:485-6.

4. 4.Kroll MH,Hagendruber C,Elin RJ. Reaction of picrate with creatinine and cepha antibiotics. Cli Chem 1984; 30: 1664-6.

5. Bowers LD, Wong ET. Kinetic serum creatimne assays. II. A critical evaluation and review. Clin Chem 1980;26:555-61.

6. Weber JA, van Zanten AP. Interference in current methods for measurements of creatinine. Clin Chem 1991;37:695-700. 
7. Daugherty NA, Hammond KB, Osberg IM. Bilirubin interference with the kinetic Jaffe method for serum creatinine. Clin Chem 1978;24:392-3.

8. 8.Watkins RE,Feldkamp CS,Thibert RJ,Zak B. Interesting interference in a direct serum cretinine rection.Microchem J 1976;21:370-84.

9. Soldin SJ, Henderson L, Hill JG. The effect of bilirubin and ketones on reaction rate methods for the measurement of creatinine. Clin Biochem 1978;11:82-6.

10. Jendrassik L, GrofP. Vereinfachte photometrische Methoden zur Bestimmung des Biut Bilirubins. Biochem Z 1938;297:81-9.

11. Coutinho CB, Lucek RW, Cheripko JA, Kuntzman R. A new approach to the determination ofprotein-bound bilirubin displacement and its applications. Ann N Y Acad Sci 1973226:238-46.

12. Franzini C, Cattozo G. Caffeine-splitting of bilirubin/albumin complex: its relevance to the spectrophotometry of biiirubin in serum. Clin Chem 1987;33:597-9.

13. Lolekha PH,Sritong N. Comparison of techniques for minimizing interference of bilirubin on serum cretinine determined by the kinetic Jaffe rection.J Clin Lab Anal 1994;8:391-9.

14. Prabhat Kumar Nigam. Bilirubin Interference in Serum Creatinine Estimation by Jaffe's kinetic Method and Its Rectification in Three Different Kits. Ind J Clin Biochem (Apr-June 2016) 31(2):237-9.

15. Bowers LD, Wong ET. Kinetic serum creatinine assays. II. A critical evaluation and review. Clin Chem 1980;26:555-61.

16. Jendrassik,L., Grof, P., (1938) Biochem. 2,297:81.

17. Bowers, L.D.(1980) Clin. Chem. 26:551.

18. Bowers, L.D. et al.(1980) Clin. Chem. 26:655.

19. Fawcett, J.K., Scott, J.E., (1960) J.Chim.Pathol.13:156.

20. Chaey, A.(1962) Clin. Chem.8:130.

21. Smith-Palmer T. Separation methods applicable to urinary creatine ans Creatinine. J Chromatogr B 2002;781:93-106.

22. Tsikas D, Wolf A, Frolich JC, Simplified HPLC method for urinary and circulating Creatinine. Clin Chem 2004;781:93.

23. Brodersen R, Bartels P. Enzymatic oxidation ofbilirubin. Eur. J Biochem 1969;10:468-73.

24. Tanaka N, Murao S. Reaction of bilirubin oxidase produced by MT-1.Agric Bio Chem 1985;49:843-4.

25. Perry B, Doumas BT, Buffone G, Glick M, Ou C-N, Ruder K. Measurements of total bilirubin by use of bilirubin by use of bilirubin oxidase. Clin Chem 1986;32:329-32.

26. Bratlid D. The effect of antimicrobial agents on bilirubin binding by human erythrocytes. Scand J Clin Lab Invest 1972;30:331-7.

27. Nguyen D. Cherruay B. Jaffray P, Younger J.Interference of Bilirubin in Creatinine Jaffe's estimation. Ann Bio Clin 1988;46:701-3.

28. Goran Rajs, Michael Mayer, Oxidation markedly reduces bilirubin interference in Jaffe Creatinine assay. Clin Chem 1992;38/12,2411-2413.

29. Greenberg N, Robert WL, Bachmann LM, Wright EC, Dalton RN, Zakowski JJ, Miller WG. Specificity characteristics of 7 commercial creatinine measurement procedures by enzymatic and Jaffe method principles. Clin Chem. 2012;58:391-401.

30. Peake M, Whiting M. Measurement of serum creatinine - current status and future goals. Clin Biochem Rev. 2006;27:173-84.
31. Lolekha PH, Jaruthunyaluck S, Srisawasdi P. Deproteinization of serum: another best approach to eliminate all forms of bilirubin interference on serum creatinine by kinetic Jaffe reaction. J Clin Lab Anal. 2001;15:116-21. 